\title{
Expenditure Effects of \\ Intergovernmental Transfers - the Case of Slovenia
}

\author{
UDK: $336.1: 352(497.4)$ \\ Primož Pevcin \\ University of Ljubljana, Faculty of Administration \\ primoz.pevcin@fu.uni-li.si
}

\section{ABSTRACT}

The purpose of this paper is to provide the evidence on the "stickiness" of intergovernmental transfers. Namely, intergovernmental transfers have fiscal (expenditure) effects as they stimulate provision of local government goods and services, and this expenditure effect should be larger for the matching grants and smaller for lump-sum transfers. It is also expected that this effect would be larger than the equivalent increase in local income, prediction labelled as flypaper effect when related to lump-sum transfers. Empirical research for Slovenian municipalities provides the evidence that the magnitude of expenditure effects of various categories of intergovernmental transfers is substantially lower compared to international findings, and in some cases the effect is even smaller than the effect of per-capita income.

Key words: local public finances, intergovernmental transfers, expenditure effect

JEL: HTI

\section{Introduction}

The purpose of this paper is to provide the evidence on the "stickiness" of intergovernmental transfers in specific context of post-socialist country. Intergovernmental transfers have fiscal (expenditure) effects as they stimulate provision of local government goods and services. One of the first systematic discussions on the fiscal effects of intergovernmental transfers has been developed by Gramlich \& Galper (1973). They have classified the intergovernmental transfers into three types: (1) open-end

Pevcin, P. (2011). Expenditure Effects of Intergovernmental Transfers the Case of Slovenia. Uprava IX(4), 31-46. 


\section{Expenditure Effects of Intergovernmental Transfers - the Case of Slovenia}

matching grants, where the higher level of government pays some portion of the cost of certain expenditures of lower level of government, which effectively reduces the price of services delivered by local government; (2) closed-end lump-sum transfers, where the higher level of government basically transfers a fixed amount of money to a lower level of government without imposing any restrictions on the use of money or changing any relative prices; and (3) closed-end categorical grants, where the higher level of government transfers a limited amount of money to be used for a specific programme implemented by lower level of government, which actually means that this type of grant is a hybrid of the first two types (price of the programme is lowered, yet the size of the grant is limited). The authors have pointed out that the expenditure effect should be larger for the open-end matching grants and smaller for closed-end lump-sum transfers, whereas the expenditure effect of closed-end categorical grants should be somewhere in between of those two effects. ${ }^{1}$

Besides, Gramlich \& Galper (1973) have also pointed out that lumpsum transfers have larger effect on government spending than equivalent increase in private income - they have labelled that phenomenon as the "fly-paper theory of incidence», since «money sticks where it hits «. ${ }^{\mathbf{2}}$ Namely, the empirical findings have shown that lump-sum transfers of central government tend to have greater stimulatory effect on local government spending than the equivalent increase in the income of the median voter (see, e.g., Brennan \& Pincus, 1996; Strumpf, 1998). ${ }^{3}$ This means that fly-paper effect actually contradicts traditional theory of grantsin-aid of exhaustive governmental expenditures (see Bradford \& Oates, 1971; Bailey, 1999), which is based on median voter theorem of public choice. Namely, this theorem states that intergovernmental transfers and voter income should have identical effects on local government expenditure (Wyckoff, 1988). Nevertheless, empirical research has shown that local authorities tend to spend those transfers rather to pass such transfers to local residents in the form of tax cuts.

\footnotetext{
1 In other words, lump-sum grants have only an income effect, whereas matching grants have also substitution effect.

2 It is worth stressing that fly-paper effect prediction refers only for lump-sum transfers (see also Acosta, 2010).

3 The label fly-paper effect was first delivered by Okun (see Hines \& Thaler, 1995).
} 


\section{The literature on the expenditure effects of intergovernmental transfers}

It is worth noting that fly-paper effect has been extensively addressed in literature, since the problem of unequal response of local government expenditures on equal increase in local community income and lump-sum transfers has been observed in many empirical studies on cross-sectional variation in intergovernmental transfers, although the majority of studies tend to focus on industrialised countries (Acosta, 2010). In fact, the flypaper effect was one of the main concerns in the earlier literature on intergovernmental transfers. Modelling of the fly-paper effect has been based on various assumptions, such as voters facing fiscal illusion and absence of political competition, self-interest of politicians and imperfections in the political system etc. (Gamkhar \& Shah, 2007).

In general, four possible explanations for the observed fly-paper effect phenomenon have been provided in the empirical literature (Inman, 2008). First possible explanation focuses on the data and states that intergovernmental transfers are miss-measured, since matching grants tend to be equalised with lump-sum aid. ${ }^{4}$ Namely, the former has a price effect as it lowers the marginal price of public services, whereas the latter has only an income effect. ${ }^{5}$ Second possible explanation sees the phenomenon basically as the consequence of econometric problem. Namely, the fly-paper effect should be the consequence of misspecifications of the technology and costs of providing services in the local level, which should occur due to the failure to correctly validate the possibility of citizen exit from high tax jurisdictions. ${ }^{6}$ Third possible explanation focuses on the possibility of misspecification of citizen fiscal choices, as citizens may not understand the complexity of grant programmes. Finally, the last possible explanation, maybe most promising, sees the phenomenon as a consequence of politics. This explanation actually complements voter ignorance hypothesis in a sense that voters perceive aid's budgetary effects, yet they allocate public and

4 In other words, fly-paper effect may be observed when matching grants are mistaken for lump-sum transfers, as matching grants tend to have larger expenditure effects than lumpsum transfers. This indicates that caution should be taken when interpreting fly-paper effect. More on the possible grant misspecification see Bailey (1999).

5 Nevertheless, several authors have argued that fly-paper effect still remains, even if matching grants and aid programmes are correctly classified (see Wyckoff, 1991).

6 More on this see also Worthington \& Dollery (1999). 


\section{Expenditure Effects of Intergovernmental Transfers - the Case of Slovenia}

private money through separate »mental accounts"; public budget is taken as the responsibility of government and private budget as individual responsibility. Consequently, fly-paper effect exists as a consequence of incentives of elected politicians and is thus influenced by political system. ${ }^{7}$

Economic theory has provided several theoretical concepts to explain the phenomenon of the fly-paper effect. First, the median voter theory argues that the fly-paper effect should be the result of mistakes in research methods, whereas Leviathan model of budget maximising behaviour contemplates that fly-paper is the result of local politicians using their monopoly power over budget information to increase their budgets, either to deceive voters for gaining support for larger expenditures or to hide the intergovernmental grants from voters (see Bae \& Feiock, 2004). Finally, the last approach is based on the concept of "fiscal illusion", since the citizens ignore that intergovernmental transfers lower the real price for the provision of public goods at the local level, which means that those funds could be implicitly refunded to them in the form of tax cuts (Sour \& Giron, 2009). In this context, this concept predicts that government actually produces the output demanded by the median voter, although this demand is based on misperceptions how the public goods are financed and what is their own share in bearing the costs of production (Widariono, 2006).

As already mentioned, numerous studies have tested the expenditure effects of intergovernmental transfers and possible existence of fly-paper effect in local authority financing (see e.g. Hines \& Thaler (1995), Becker (1996), Turnbull (1998), Bailey \& Connolly (1998), Worthington \& Dollery (1999), Knight (2002), Inman (2008), Sour \& Giron (2009), Acosta (2010), just to name a few out of vast array of research in this field). For instance, Inman (2008) has reported that, according to Google Scholar search engine, until 2008 more than 3,500 papers have been written dealing with the issue of fly-paper effect. Yet, it needs to be acknowledged that some studies were not able to confirm the validity

7 More on this see Hines \& Thaler (1995). Consequently, this explanation stresses that flypaper is not anomaly but rather reality of fiscal policies. In fact, as Rodden (2006) has argued in his revision of Hamilton's paradox, a negative effect of decentralised government finance is associated with the moral hazard problem, which is even inflated if sub-national governments are funded primarily through revenue-sharing and grants. In this case centre dominates the power to tax and takes on heavy obligations on funding of subnational governments, which causes that officials of sub-national governments face weak incentives for fiscal discipline. 
of effect. For instance, Becker (1996) has even argued that fly-paper effect is actually a statistical artefact, since inappropriate functional form of estimation may generate the illusion of fly-paper effect presence. Moreover, Bailey (1999) has presented an overview of potential factors causing overestimation in the size of the fly-paper effect. Those factors include possible misspecification of the type of intergovernmental grant, use of an inappropriate function form in regression analysis, and use of inappropriate explanatory (control) variables in the regression analysis. ${ }^{8}$

\section{Empirical evidence on the expenditure effect of intergovernmental transfers across Slovenian municipalities}

Consequently, the purpose of this study is to examine the magnitude of expenditure effects of intergovernmental transfers and to test possible existence of fly-paper effect for a cross-section of 210 Slovenian municipalities in 2009. ${ }^{9}$ The reduced-form regression model for local government expenditure is:

$$
E X P_{i}=B X_{i}+U_{i}
$$

where EXP $P_{i}$ is total expenditure per capita for municipality $i, X_{i}$ represents explanatory variables that affect municipal expenditure level in the sample period, and $v_{i}$ describes unobservable shocks to municipal spending. Expenditures of Slovenian municipalities include current and investment expenditures and transfers, given loans and capital investments, as well as debt repayments. According to the Local Self-Government Act (2007),

8 The empirical analysis, presented in the next chapter, focuses only on estimation of expenditure effects of intergovernmental transfers received by Slovenian municipalities, in order to avoid the problem of grant type misspecification.

9 It needs to be stressed that cross-sectional data are used in the analysis. There are several reasons for using those data: (1) several other existing empirical studies have used cross-sectional data (more on this see Amusa, Mabunda \& Mabugu, 2008; Acosta, 2010); (2) there are problems with achieving consistent time series data for Slovenian municipalities, given the fact that their number has risen constantly and substantially in last 17 years, predominantly with devolutions of existing municipalities; (3) given the previous observation, substantial changes in the legislation on municipal finances happened in last few years (the last modification appeared in 2008 and became valid for 2009 fiscal year), contributing to the fact that data comparison between different fiscal years could be problematic. Furthermore, it needs to be stressed there is no intermediate level of local authorities (i.e. regions), although both professional and political discussions on this issue have existed. See, e.g. readings in Setnikar-Cankar \& Šević (2008) on administrative, economic, organisational and fiscal perspectives of regionalisation in Slovenia. 
municipalities perform local matters of public interest in order to meet the needs of their residents. Specifically, municipalities manage the municipal assets and organise municipal administration, develop conditions for economic development of the municipality, provide spatial development plans and create conditions for housing, manage and regulate local public utilities and local public services provision, provide social services (in particular pre-school and primary school education, social, cultural and recreational activities etc.), organise local road maintenance, fire safety etc. ${ }^{10}$ These so-called own functions of municipalities are planned in the municipal budget formulated for the period of a single (fiscal) year. Table below summarises expenditures of Slovenian municipalities by function.

\section{Table 1: Consolidated expenditures (functional classification) of Slovenian} municipalities, 2009 (in million EUR)

\begin{tabular}{|l|r|}
\hline Public administration & 429.38 \\
\hline Defence & 3.46 \\
\hline Public order & 43.58 \\
\hline Public utilities & 522.91 \\
\hline Environment protection & 207.21 \\
\hline Housing and spatial development & 182.13 \\
\hline Health & 16.12 \\
\hline Recreation, culture and activities of NGO's & 244.28 \\
\hline Education & 484.34 \\
\hline Social security & 102.18 \\
\hline Total & $2,235.59$ \\
\hline
\end{tabular}

Source: Ministry of Finance, 2011.

In contrast, municipalities in Slovenia receive their resources from tax revenues, non-tax revenues, capital revenues, donations, transfers and EU funds. Specifically, Act on Local Finances ZFO-1A (2008) envisages and specifies that municipalities in Slovenia finance their activities from following resources: (1) own tax revenues, which include revenues from

10 See the act on detailed description of municipal tasks. It needs to be stressed that large differences in the size of municipalities exist, and there is no intermediate level of local authorities (i.e., regions). In particular, Slovenia is a relatively centralised country, given the fact that approximately nine tenths of total government spending is allocated by central government (Government Office for Local-Self Government and Regional Policy, 2006). 


\section{Primož Pevcin the Case of Slovenia}

inheritance and gift taxes, property taxes, taxes on profits from lotteries and gaming, taxes on real estate business transactions, $54 \%$ of personal income tax paid by municipal residents ${ }^{11}$, etc.; (2) other own revenues, which include administrative fees and duties, concession duties and municipal communal rates, revenues from public utilities, environmental duties, revenues derived from the municipal property management, donations, transfers from central government budget, etc.; (3) municipal duties, which include compensation fees for use of municipal land, etc.; and (4) borrowing, although the amount of municipal borrowing is limited by the law.

\section{Table 2: Consolidated revenues of municipalities in Slovenia (excluding borrowing and financial investments), 2009 (in million EUR)}

\begin{tabular}{|l|l|}
\hline Tax revenues & $1,295.31$ \\
\hline Non-tax revenues & 256.17 \\
\hline Capital revenues & 97.12 \\
\hline Donation & 3.86 \\
\hline Transfers & 382.37 \\
\hline EU funds & 1.73 \\
\hline Total & $2,036.56$ \\
\hline
\end{tabular}

Source: Ministry of Finance, 2011.

The Act on Local Finances (1998) introduced a system of appropriate expenditure in order to allow municipalities to carry out their constitutional and legal responsibilities. According to this system, last amended in 2007 fiscal year (Act on Local Finances ZFO-1, 2006) ${ }^{12}$, appropriate expenditure is calculated on the basis of a special equation, which includes correctional factors for diversity in municipalities for the purpose of achieving the equalisations (in comparison to national average), such as the spatial size of municipality, number of residents, number of residents aged below 15 and above 65 and the length of local roads. Local Self-Government Act (2007) stipulates that municipalities must raise

11 This source tends to be the most important one in practice (see Ministry of Finance, 2010).

12 Basically, the model of calculation of $i$-th municipality appropriate expenditure has been amended in the sense that weights of correctional factors have been changed and the average municipal costs per capita needed for financing of their tasks has been introduced as a basis for appropriate expenditure calculation. See the law for the exact formula. 


\section{Expenditure Effects of Intergovernmental Transfers - the Case of Slovenia}

their own revenue. Financially disadvantaged municipalities, unable to fully perform their duties, are eligible to receive additional financial assistance from the state in accordance with the principles and criteria prescribed by the law. This actually means that municipalities, where own resources may not be sufficient to finance provision of the services that certain municipality is obliged to deliver, are eligible to receive special financial equalisation from central government budget. ${ }^{13}$ This actually means that spending on municipal constitutional and legal responsibilities does not depend (solely) on municipal revenues, but rather on "certain objective" factors that influence costs of municipalities. Taking this into account, it is expected that expenditure effects of intergovernmental transfers should be lower than in countries where the amount of municipal (or other lower government tiers) spending more depends on revenues obtained. ${ }^{14}$

Municipal expenditure categories considered in the analysis correspond to total expenditures, which means that both current and investment expenditures and transfers, as well as loans given and debt repayments are included. As already noted, municipalities in Slovenia receive resources from many sources, including transfers. Intergovernmental transfers considered in the analysis are those received from central government budget as well as from other public funds and agencies, including also possible financial equalisation. Specifically, intergovernmental transfers are classified into three categories: total transfer revenues; transfer revenues from central government budget; and transfers from central government budget excluding financial equalisation.

13 In other words, municipalities with insufficient own revenues to finance municipal appropriate expenditures, receive additional revenues in order to be able to perform their duties (see Act on Local Finances ZFO-1A, 2008). Both economic and social rationale exist for introduction of financial equalisation, such as relatively small size of municipalities, limited scope for user-charging due to the potential negative social impacts and high collection costs, not to mention the directives of European Charter of Local SelfGovernment (1985), which in Article 9 supports the institution of financial equalisation that ought to correct the effects of unequal distribution of potential financial sources and burdens of local authorities. More on the financial equalisation see also Bailey (1999). On aggregate, financial equalisation amounted approximately 54 million EUR in 2009, which is not substantial when compared to total revenues of municipalities, although 191 municipalities received that kind of central government support (Ministry of Finance, 2011).

14 For the review of the literature on the local government system and description of the problems associated with municipal finances in Slovenia see, e.g., Setnikar-Cankar et al. (2000), Oplotnik \& Brezovnik (2004), Vlai (2004) and Brezovnik et al. (2006). 


\section{Primož Pevcin \\ Expenditure Effects of Intergovernmental Transfers - the Case of Slovenia}

Consequently, the empirical study would also like to examine the variations in magnitude of expenditure effects of different categories of transfers. Municipal expenditure and transfer data were obtained from the Ministry of Finance.

Regression analysis uses per capita municipal total expenditures as dependent variable. Covariates used in the analysis are aforementioned per capita municipal transfer revenues, per capita income ${ }^{15}$, which relates to idea that available income should be the other important prerequisite for municipal spending, consequently making the possibility to test the existence of fly-paper effect. All those variables are expressed in log terms. Besides, the analysis also includes additional control variables such as expenditures needs (LNEEDS), to control for the ability of municipality to meet the demands for local public goods provision ${ }^{16}$, total municipal population (POP), to control for potential scale effects, density - municipal population per squared kilometre of territory (DENS) - to control for potential congestion effects, proportion of population unemployed (UNEMP), proportion of population older than 65 years $(65+)$ and proportion of population younger than 15 years (15-), all variables included with the purpose to control for group-specific demands, predominantly of those groups within population, which have relatively larger demand for public spending. ${ }^{17}$ These control variables are integrated into the model, since the majority of them tend to be standard in the empirical literature on fly-paper effects (for instance, see Worthington \& Dollery, 1999; Amusa, Mabunda \& Mabugu, 2008; Acosta, 2010 etc.). For instance, the exposition given in Worthington \& Dollery (1999) specifies expenditure function for governmental provided goods as the function of the total amount of resources that are available

15 Average monthly gross salary per employed person in i-th municipality is used as proxy for describing per capita income, since those data are available also at municipal level. Source of data for this variable is Statistical Office the Republic of Slovenia (2011).

16 Basically, the expenditures on administrative operation, public utilities and education are used as a proxy for describing the core functions of the municipalities, and they are all expressed in per capita terms. The expenditures for local public utilities, education and administrative operation are the most important expenditures of municipalities in Slovenia, since the provision of those services and functions is particularly in the municipal domain. Source of data for this variable is Ministry of Finance (2011).

17 Source of data for variables POP, DENS, UNEMP, 65+ and 15- is Statistical Office of the Republic of Slovenia (2011). All data relate to 2009. The data for unemployed persons are based on the so-called registered unemployment principle (National Labour Office methodology). 
for funding such expenditures, the function of the relative tax price of expenditures, and the function of institutional and other factors that affect expenditure outcomes. Descriptive statistics of the variables included in the analysis is presented in table 3.

Table 3: Descriptive statistics, Slovenian municipalities, 2009

\begin{tabular}{|l|c|c|c|c|}
\hline Variable & Mean & Max & Min & SD \\
\hline Expenditures per capita (EUR) & 1,141 & 3,911 & 161 & 453 \\
\hline $\begin{array}{l}\text { Income per capita - monthly } \\
\text { (EUR) }\end{array}$ & 1,296 & 1,975 & 753 & 159 \\
\hline Total transfers per capita (EUR) & 297 & 2023 & 1 & 276 \\
\hline $\begin{array}{l}\text { Transfers from central budget per } \\
\text { capita (EUR) }\end{array}$ & 186 & 1350 & 1 & 182 \\
\hline $\begin{array}{l}\text { Transfers from central budget } \\
\text { excluding financial equalisation } \\
\text { per capita (EUR) }\end{array}$ & 129 & 1155 & 1 & 151 \\
\hline $\begin{array}{l}\text { PA\&PU\&EDU expenditures per } \\
\text { capita (EUR) }\end{array}$ & 737 & 3,023 & 122 & 345 \\
\hline Population (in 1,000) & 9.725 & 278.314 & 0.320 & 21.761 \\
\hline Density & 113 & 1019 & 5 & 124 \\
\hline Unemployment (\%) & 11.2 & 29.0 & 4.0 & 5.0 \\
\hline Population 65+ (\%) & 16.47 & 26.89 & 12.06 & 2.29 \\
\hline Population 15- (\%) & 14.41 & 20.78 & 8.21 & 1.79 \\
\hline
\end{tabular}

Table 3 represents descriptive statistics for variables included in the empirical analysis: average municipal per capita expenditures amount to 1141 EUR per year, while average intergovernmental transfers received by Slovenian municipality amount to 297 EUR, which means that transfers represent approximately one quarter of municipal revenues. Nevertheless, descriptive statistics indicates that municipalities in Slovenia differ substantially in terms of municipal spending activities, size and population structure, and also in economic activity. 
Table 4: Estimates of expenditure effects ${ }^{18}$

\begin{tabular}{|l|c|c|c|}
\hline Estimation & $(1)$ & $(2)$ & $(3)$ \\
\hline Lincome & $0.1083(0.0755)$ & $0.1059(0.0844)$ & $0.0871(0.0856)$ \\
\hline Ltransfers & $0.1548(0.0217)$ & $0.0813(0.0200)$ & $0.0719(0.0182)$ \\
\hline Lneeds & $0.5536(0.0451)$ & $0.6768(0.0399)$ & $0.6833(0.0405)$ \\
\hline pop & $-0.0017(0.0006)$ & $-0.0014(0.0007)$ & $-0.0012(0.0007)$ \\
\hline dens & $0.0007(0.0002)$ & $0.0005(0.0002)$ & $0.0004(0.0002)$ \\
\hline unemp & $-0.0058(0.0020)$ & $-0.0044(0.0025)$ & $-0.0034(0.0024)$ \\
\hline $65+$ & $0.0044(0.0055)$ & $0.0080(0.0060)$ & $0.0088(0.0058)$ \\
\hline $15-$ & $-0.0087(0.0081)$ & $-0.0117(0.0086)$ & $-0.0084(0.0086)$ \\
\hline Intercept & $1.8217(0.6941)$ & $1.4507(0.7189)$ & $1.5616(0.7222)$ \\
\hline Observations & 210 & 210 & 210 \\
\hline R2adj. & 0.832 & 0.780 & 0.780 \\
\hline SEE & 0.138 & 0.158 & 0.158 \\
\hline Durbin-Watson & 1.853 & 1.832 & 1.887 \\
\hline F-stat. & 130.76 & 93.46 & 93.60 \\
\hline Reset p & 0.268 & 0.638 & 0.469 \\
\hline
\end{tabular}

Table 4 represents ordinary least squares estimation for a local (municipal) expenditure function for 2009. Evidently, if total transfer revenues are taken into account (column 1), the results suggest that flypaper effect exists. Namely, the elasticity of municipal expenditures with respect to per capita income is approximately 0.108 , while the coefficient on per capita transfers is higher, approximately 0.155 , which means that discrepancy amounts to almost 5 eurocents. Regarding the other covariates, there seems to be statistically significant evidence on rather weak scale and congestion effects, as municipal expenditures per capita tend to decrease with the size of the municipality, and increase with population density. Increasingly, municipalities with a greater proportion of groups with high demand for public goods and services do not necessarily have higher expenditure levels, although this statement should be taken with caution as only the unemployment rate is statistically significant (but only in two instances). ${ }^{19}$ Interestingly, if transfers

18 Dependent variable: lexpenditures. White heteroscedasticity-consistent standard errors in parentheses.

19 In fact, one should expect that demand of elderly and young population can already be observed in per capita expenditure levels, as they represent criteria for municipal 


\section{Expenditure Effects of Intergovernmental Transfers - the Case of Slovenia}

from central budget (with or without financial equalisation) are taken as covariates in the regression function (columns 2 and 3), the existence of fly-paper effect could not be observed, as the elasticity of municipal expenditures with respect to per capita income is approximately 0.106 (0.087), while the coefficient on per capita transfers is lower, approximately 0.081 (0.072). ${ }^{20}$

These estimates obviously suggest that the evidence on the existence of fly-paper effect is inconclusive, as the selection of the type of transfer category influences the magnitude of the elasticity of municipal expenditures. Moreover, if the findings from the column 1 would be accepted, the estimated fly-paper effect is relatively small in magnitude, especially compared to some other international findings. Interestingly, the magnitude of income elasticity is in the range predicted from the evidence in the literature, yet the impact of transfers is substantially lower. ${ }^{21}$ Notwithstanding, it should be acknowledged that the impact of income is problematic if statistical significance is taken into account, suggesting that municipal expenditures tend to depend on other factors, rather than income, denoting also potential problems in the system of local government expenditure formation and formulation.

\section{Concluding remarks}

The purpose of the study presented in the paper is related to the investigation of expenditure effects of intergovernmental transfers in municipal financing system in Slovenia. The empirical research indicates

appropriate expenditure calculations. Ultimately, if the $\chi^{2}$ test is followed and variables $65+$ and 15- would be left out of the model where appropriate, the expenditure elasticity with respect to income and transfers would change only slightly. Nonetheless, all three existing regression functions seem to be structurally stable.

20 Interestingly, the values of coefficients on per capita transfers are very low, although the intergovernmental grants have not been structured. Namely, the theory predicts that expenditure effects should be larger for matching grants than for lump-sum grants. This means that specific focus only on lump-sum grants would possibly even lower the values of coefficients, thereby even further restraining the possibility for finding evidence on larger elasticity of intergovernmental transfers compared to elasticity of income.

21 For instance, Case et al. (1993) have pointed out that income elasticity should be in the range between 0.05 and 0.10 , while the impact of transfers should be above 0.40 . Similar impact of transfers has also been proposed by Gramlich \& Galper (1973). Interestingly, Acosta (2010) has suggested the income effect of around 0.50 and transfer effect of around 0.65. Nevertheless, Bailey (1999) has argued that one potential pitfall of numerous studies is that the magnitude of fly-paper effect is overestimated, as some authors do not explicitly differentiate matching grants and lump-sum transfers. 


\section{Primož Pevcin \\ Expenditure Effects of Intergovernmental Transfers - the Case of Slovenia}

inconclusive findings on the magnitude of expenditure effects of various categories of intergovernmental transfers to municipalities, which presents the problem also for possible validation of the fly-paper effect, although study does not specifically structure intergovernmental grants in Slovenia. Namely, the empirical findings presented in study indicate that the estimated magnitude of expenditure effect of intergovernmental transfers is substantially lower compared to results presented in some other international empirical studies, notwithstanding the fact that this magnitude should be even lower for some types of grants. It should also be mentioned that the effect of per-capita income is technically speaking not statistically significant, suggesting limited dependence of municipal spending on per-capita income as one of the most important sources of tax (on some other own) revenues. ${ }^{22}$ Given the fact that this is an exploratory study, the issue of expenditure and fly-paper effect should be empirically addressed further, in particular in post-socialist countries. Potential research should be focused at the examination of the expenditure effects of various categories of intergovernmental transfers, although the distinction between matching grants and lump-sum transfers can be difficult in practice, so this classification has been avoided in the paper. Nonetheless, the research has pointed out that narrowing the intergovernmental expenditures has negatively affected the magnitude of expenditure effect. This potentially indicated that the presence of the flypaper effect in practice is very disputable, since it is expected that matching grants with potentially larger expenditure effects would prevail in transfers from other public sector units rather than central government. Yet, we should still be aware that any revelation of the existence of the flypaper effect somehow indicates the inefficiencies in the management of local government expenditures.

Primož Pevcin, Ph.D. is assistant professor for public sector economics at the Faculty of Administration, University of Ljubliana. His teaching and research work focuses primarily on the field of public and non-profit management and economic theory of politics.

22 The problem of insufficient relations between municipal expenditures and revenues in Slovenia has already been addressed by Oplotnik \& Brezovnik (2004). Some legal amendments concerning this issue have been made in last few years, although they still tend to be insufficient according to the evidence presented in the study. 


\section{References}

- (1985). European Charter of Local Self-Government. Strasbourg: Council of Europe.

- (1998). Act on Local Finances. Official Gazette of RS, 56/98.

- (2006). Act on Local Finances ZFO-1. Official Gazette of RS, 123/2006.

- (2007). Local Self-Government Act. Official Gazette of RS, 94/2007.

- (2008). Act on Local Finances ZFO-1A. Official Gazette of RS, 57/2008.

- Acosta, P. (2010). The "fly-paper effect" in presence of spatial interdependence: evidence from Argentinean municipalities. Annals of Regional Science (44), 453-466.

- Amusa, H., Mabunda, R. \& Mabugu, R. (2008) Fiscal Illusion at the Local Sphere: An Empirical Test of the Flypaper Effect using South African Municipal Data. Working Paper n. 72, Financial and Fiscal Commission.

- Bae, S. \& Feiock, R.C. (2004) The Flypaper Effect Revisited: Intergovernmental Grants and Local Governance. International Journal of Public Administration (27), 577-596.

- Bailey, S.J. \& Connolly, S. (1998). The Flypaper Effect: Indentifying Areas for Further Research. Public Choice (95), 335-361.

- Bailey, S.J. (1999). Local Government Economics. Basingstoke: Macmillan Press.

- Becker, E. (1996). The Illusion of Fiscal Illusion: Unsticking the Flypaper Effect. Public Choice (86), 85-102.

- Bradford, D. \& Oates, W. (1971). Towards a Predictive Theory of Intergovernmental Grants. American Economic Review (61), 440-448.

- Brennan, G. \& Pincus, J.J. (1996). A minimalist model of federal grants and flypaper effects. Journal of Public Economics (61), 229-246.

- Brezovnik, B., Oplotnik, Ž. \& Železnik, M. (2006). Analize za prenovo sistema financiranja samoupravnih lokalnih skupnosti. Ljubljana: Služba vlade RS za lokalno samoupravo in regionalno politiko. Retrieved 10. 10. 2011 , from http://www.svlr.gov.si/

- Case, A., Rosen, H. \& Hines, J. (1993). Budget spillover and fiscal policy interdependence: evidence from the States. Journal of Public Economics (52), 285-307.

- Gamkhar, S. \& Shah, A. (2007). The Impact of Intergovernmental Fiscal Transfers: A Synthesis of the Conceptual and Empirical Literature. In: Boadway, R. \& Shah, A. (Eds.). Intergovernmental Fiscal Transfers: Principles and Practice. Washington: The World Bank.

44 Uprava, letnik IX, 4/2011 
- $\quad$ Government Office for Local-Self Government and Regional Policy (2006). The changes in the system of municipal financing. Ljubljana: SVLR.

- Gramlich, E.M. \& Galper, H. (1973). State and Local Fiscal Behavior and Federal Grant Policy. Brookings Papers on Economic Activity (1), 15-65.

- Hines, J.R. \& Thaler, R.H. (1995). Anomalies: The Flypaper Effect. Journal of Economic Perspectives (9), 217-226.

- Inman, R.P. (2008). The Flypaper Effect. Working Paper 14579. Cambridge: NBER.

- Knight, B. (2002). Endogenous Federal Grants and Crowd-Out of State Government Spending: Theory and Evidence from the Federal Highway Aid Program. American Economic Review (92), 71-92.

- Ministry of Finance (2010). Calculations of the appropriate expenditures of local authorities and needed financial equalizations, 2003-2009. Ljubljana: RS, Ministry of Finance.

- Ministry of Finance (n.d.). Financial Statements of Municipalities. Retrieved 12. 9. 2011 , from http://www.mf.gov.si/

- $\quad$ Oplotnik, Ž. \& Brezovnik, B. (2004). Financing local government in Slovenia. Post-Communist Economies (16), 483-496.

- Rodden, J. (2006). Hamilton's Paradox: The Promise and Peril of Fiscal Federalism. Cambridge: Cambridge University Press.

- Setnikar-Cankar, S., Klun, M. \& Vlaj, S. (2000). Local Government in Slovenia. In: Horvath, T. (Ed.). Decentralization: Experiments and Reforms. Budapest: OSI/LGI.

- Setnikar-Cankar, S. \& Šević, Ž. (Eds.) (2008). Decentralisation and regionalisation: the Slovenian experience in an international perspective. London: Greenwich University Press; Ljubljana: Faculty of Administration.

- Sour, L. \& Giron, F. (2009). Electoral Competition and the Flypaper Effect in Mexican Local Governments. Paper n. 238. Mexico-Toluca: CIDE.

- Statistical Office of the Republic of Slovenia (n.d.). SI-Stat Data Portal. Retrieved 15. 9.2011, from http://www.stat.si/

- Strumpf, K.S. (1998). A predictive index for the flypaper effect. Journal of Public Economics (69), 389-412.

- Turnbull, G.K. (1998). The Overspending and Flypaper Effects of Fiscal Illusion: Theory and Empirical Evidence. Journal of Urban Economics (44), $1-26$.

- Vlaj, S. (2004). Lokalna samouprava: Teorija in praksa. Ljubliana: Fakulteta za upravo. 
- Widariono, A. (2006). Does intergovernmental transfers cause flypaper effect on local spending?, Jurnal Ekonomi Pembangunan (1 1), 115-123.

- Worthington, A.C. \& Dollery, B.E. (1999). Fiscal Illusion and the Australian Local Government Grant Process: How Sticky is the Flypaper Effect? Public Choice (99), 1-13.

- Wyckoff, P.G. (1988). A Bureaucratic Theory of Flypaper Effects. Journal of Urban Economics (23), 115-129.

- Wyckoff, P.G. (1991). The Elusive Flypaper Effect. Journal of Urban Economics (30), 310-328.

46 Uprava, letnik IX, 4/2011 
POVZETEK

\section{IZDATKOVNI UČINKI TRANSFERNIH PRIHODKOV LOKALNIH OBLASTI - PRIMER SLOVENIJE}

Ključne besede: lokalne javne finance, transferni prihodki občin,
izdatkovni učinki

Namen prisperka je predstaviti empirične dokaze o "lepliivosti" transfernih prihodkov lokalnih oblasti $v$ specifičnem kontekstu postsocialistične države. Namreč, transferni prihodki lokalnih oblasti imajo fiskalne (izdatkovne) učinke, saj spodbujajo zagotavljanje (proizvodnjo) lokalnih javnih dobrin in storitev. Natančneje, lump-sum (pavšalni) transferji naj bi imeli večji učinek na lokalno javno porabo kot enakovredno povečanje dohodkov rezidentov - gre za tako imenovan učinek muholovke, ki označuje "lepljivost" tako pridobljenih sredstev lokalnih oblasti. Ugotovitve empiričnih študii kažejo, da pavšalni transferji centralnih oblasti k lokalnim oblastem povzročajo večji stimulacijski učinek na lokalno javno porabo kot enakovredno povečanje dohodka sredinskega volivca. Učinek muholovke je pogosto obravnavan v literaturi, čeprav je večina študii usmerjenih na razvite industrijske države, medtem ko je ta problem relativno redko obravnavan $v$ nerazvitih ter tudi postsocialističnih državah. Na primer, tako je ameriški raziskovalec Inman leta 2008 poročal, da je Googlov iskalnik Scholar zaznal že več kot 3500 raziskav na to temo. Čeprav je večina študij lahko potrdila veljavnost tega pojava $v$ praksi, pa so ga nekatere študije tudi ovrgle. Nekateri avtorii celo trdijo, da je učinek muholovke pravzaprav statističen pojav, saj lahko neustrezna metodologija ocenjevanja ustvari iluzijo o prisotnosti tega učinka. Poleg tega je $v$ teoriji mogoče zaslediti tudi pregled drugih mogočih dejavnikov, ki povzročajo precenjevanje dejanske velikosti tega učinka, kot so napačna razvrstitev posameznih transferjev, uporaba neustrezne funkciiske oblike regresijskega modela ter uporaba neprimernih pojasnjevalnih spremenliivk v ekonometrični analizi.

Glede na navedeno je glavni namen študije preučitev velikosti izdatkovnih učinkov transfernih prihodkov lokalnim oblastem ter preveritev morebitnega obstoja učinka muholovke $v$ financiranju slovenskih občin $v$ letu 2009. Odhodki slovenskih občin namreč zajemajo tekoče in investicijske odhodke in transferje, dana posojila in kapitalske naložbe ter 
odplačila dolga, pri čemer skladno z zakonodajo občine opravljalo lokalne zadeve javnega pomena za zadovoljevanje potreb svojih prebivalcev. Natančneje, občine skrbijo za upravljanje občinskega premoženja in organizacijo občinske uprave, oblikovanje pogojev za gospodarski razvoj občine, pripravljajo prostorske načrte za razvoj in stanovanjsko gradnjo, upravljanje in izvajanje lokalnih javnih služb, zagotavljanje določenih družbenih storitev (predvsem predšolsko in osnovnošolsko izobraževanje, kulturne in rekreacijske dejavnosti ipd.), vzdrževanje lokalnih javnih cest itd. Po drugi strani občine v Sloveniji za izvajanje svojih nalog pridobivajo sredstva iz davčnih prihodkov, nedavčnih prihodkov, kapitalskih prihodkov, donacii, transferjev in sredstev EU. Omeniti velja, da zakonodaja določa tudi tako imenovano primerno porabo občin, ki se nanaša na možnost opravljanja ustavnih in zakonskih obveznosti posamezne občine. $V$ povezavi s tem so finančno prikrajšane občine, ki si ne morejo zagotoviti lastnih sredstev za izvajanje zakonsko določenih nalog, upravičene do dodatne finančne pomoči države $v$ skladu z načeli in merili, ki jih predpisuje zakon (tako imenovana finančna izravnava). To dejansko pomeni, da lokalna (občinska) javna poraba ni odvisna samo od zbranih občinskih prihodkov, temveč temelji na "določenih objektivnih" dejavnikih, ki vplivajo na stroške delovanja posamezne občine. Ob upoštevanju tega je namreč smiselno pričakovati, da bodo izdatkovni učinki transfernih prihodkov nižji kot $v$ državah, kjer je lokalna javna poraba bolj odvisna od obsega zbranih prihodkov lokalnih oblasti.

$\checkmark$ bistvu so rezultati empirične ekonometrične analize pokazali, da je veljavnost učinka muholovke relativno težko potrditi. Namreč, ob upoštevanju celotnih transfernih prihodkov občin je elastičnost občinskih izdatkov glede na dohodek na prebivalca približno 0,108, medtem ko je elastičnost občinskih izdatkov glede na transferne prihodke višja in znaša približno 0,155, kar pomeni, da razlika (učinek muholovke) znaša skorai 5 centov. Vendar pa empirična analiza po drugi strani kaže, da upoštevanje samo transfernih prihodkov iz državnega proračuna (z finančno izravnavo ali breznje) povzroči, da je obstoj učinka muholovke težko potrditi, saj je elastičnost občinskih izdatkov glede na dohodek na prebivalca približno 0,106 $(0,087)$, medtem ko je elastičnost občinskih izdatkov glede na transferne prihodke nižja, saj znaša približno 0,081 $(0,072)$. Ugotovitve so zanimive zato, ker je elastičnost izdatkov glede na transferne prihodke relativno nizka, čeprav smo se $\vee$ študiji izognili 
klasifikaciji transferjev na pavšalne in nepovratne. Namreč, teorija predvideva, da naj bi bili izdatkovni učinki večji za nepovratne transferje kot za pavšalne transferje, glede na to da imajo prvi poleg dohodkovnega tudi substitucijski učinek. Tako je pričakovati, da bi usmeritev izključno na pavšalne transferje verjetno celo zmanjšala velikost izdatkovnih učinkov in $s$ tem še otežila mogočo statistično sprejemanje prisotnosti učinka muholovke.

Rezultati empirične študije, predstavljene $v$ prispevku, tako kažejo na precej omejeno možnost potrjevanja veljavnosti učinka muholovke $v$ praksi financiranja slovenskih lokalnih oblasti, pri čemer je posebej zanimivo to, da je analiza pokazala na precej nizko elastičnost občinskih odhodkov glede na transferne prihodke, zlasti v primerjavi z ugotovitvami nekaterih drugih mednarodnih študij. Izpostaviti pa velja tudi ugotovitev, da je vpliv dohodka na prebivalca na obseg občinskih odhodkov statistično neznačilen, kar kaže na to, da je lokalna (občinska) javna poraba $\vee$ veliki meri odvisna od drugih dejavnikov in ne od dohodka rezidentov, kar označuje tudi morebitno problematiko sistema lokalnih javnih financ $v$ Sloveniji. 